\title{
THE PILOT STUDY OF CHARACTERISTICS OF HOUSEHOLD WASTE GENERATED IN SUBURBAN PARTS OF RURAL AREAS
}

\author{
Aleksandra Steinhoff-Wrześniewska' \\ 1 Institute of Technology and Life Sciences, Lower Silesian Research Centre in Wrocław, Zygmunta Berlinga 7, \\ 51-209 Wrocław, Poland, e-mail: aleksandra.sw@gmail.com
}

Received: 2014.11.21

Accepted: 2015.02.04

Published: 2015.04.01

\begin{abstract}
The subject of the studies were waste generated in suburban households, in 3-bag system. The sum of wastes generated during the four analyzed seasons (spring, summer, autumn, winter - 1 year), in the households under study, per 1 person, amounted to $170,3 \mathrm{~kg}$ (in wet mass basis). For 1 person, most domestic waste was generated in autumn $-45,5 \mathrm{~kg}$ per capita and the least in winter $-39,0 \mathrm{~kg}$ per capita. The analysis performed of sieved composition (size fraction) showed that fractions: $>100 \mathrm{~mm}$, $40-100 \mathrm{~mm}, 20-40 \mathrm{~mm}$ constituted totally $80 \%$ of the mass of wastes (average in a year). The lowest fraction $(<10 \mathrm{~mm})$, whose significant part constitutes ashes, varied depending on the season of year: from $3.5 \%$ to $12.8 \%$. In the morphological composition of the households analyzed (on average in 4 seasons), biowastes totally formed over $53 \%$ of the whole mass of wastes. A significant part of waste generated were also glass waste (10,7\% average per year) and disposable nappies (8,3\% average per year). The analysis of basic chemical components of biowastes showed that in case of utilizing them for production of compost, it would be necessary to modify (correct) the ratios $\mathrm{C} / \mathrm{N}$ and $\mathrm{C} / \mathrm{P}$. Analysis of the chemical composition showed that the biowastes were characterized by very high moisture content and neutral $\mathrm{pH}$.
\end{abstract}

Keywords: household waste, biodegradably waste, rural areas, suburban areas.

\section{INTRODUCTION}

In rural areas, constituting $93 \%$ of the country's total area and inhabited by $39.8 \%$ of the population, about $20 \%$ of the total mass of municipal wastes was collected. In the prevailing legal system, the districts are the owners of wastes generated on their terrain. It is therefore advisable to study the current state (quantity and kinds) of municipal wastes so as to plan correctly shortand long-term actions concerning waste management. In the case of rural communities located in the vicinity of the city "subzones" are created. These areas are significantly different in terms of population density and building, land fragmentation, pollution from a typical rural municipality. This diversity undoubtedly creates difficulties in standardizing waste management system in such a rural community. There is only one waste management system in the municipality under current law. Organizing one common system for different areas and one rate for all residents of the municipality is difficult.

The share of municipal wastes collected from households in rural areas, in the total mass of municipal wastes collected in rural localities (villages) amounted to $75.5 \%$. However, there is lack of data regarding the quantity of municipal wastes generated on administrative areas considered as rural. The growth observed in the number of people living in rural areas, presented by Central Bureau for Statistics GUS [The results of National Census Population and Housing 2011] is to a large extent, associated with migrations from large urban centers to outskirts of towns already belonging to administrative areas distinguished as rural. Intensive housing (mostly family), the influx of urban inhabitant related to the city, very large differences in the structure of land use, coexistence of rural and urban settlement forms 
are features highly distinctive suburban areas. Formed as a result of such migration are informal (not included within administrative borders) districts, and such terrains lose their agricultural character and can significantly influence the characteristics of the rural district.

Due to large differences in households in rural districts directly bordering with large agglomerations, studies were undertaken which were aimed at analyzing the quantities, kinds and possibilities of utilizing the wastes generated in households in such areas.

\section{RESEARCH AND METHODS}

The studies were performed in 21 households administratively located in areas of rural districts directly neighbouring Wrocław. None of the analyzed households was engaged in agricultural production. All properties had areas where garden waste were formed during the growing season. Only four households were equipped with backyard composters. Neither one of the analyzed farms could develop biowaste on their property. The subject of the studies constituted all wastes generated in suburban households (with the exception of large-sized and buildings renovated) according to methodology of Jędrczak and Szpadt [Szpadt, Jędrczak, 2006]. The total number of residents in the households amounted to 83 . The number of households covered by the studies was as follows: two-person -3 , three person -3 , fourperson -10 , five-person -2 , six-person -3 . Selected farms reflect the demographic composition of population in Poland (Population. Status and demographic and social structure). In the study group of people the children under 4 years were $6.0 \%$, older children and adolescents $-30.1 \%$, of working age $-56.6 \%$ and seniors $-7,2 \%$.

The analyses were conducted during four consecutive seasons (spring, summer, autumn and winter) and the wastes were collected through 7 consecutive days, accumulated in 3-bag system:

- biowastes - kitchen and garden wastes - viz. wet,

- hygienic and utilized health-protection wastes,

- all other wastes.

The total amount of analyzed wastes was $1148 \mathrm{~kg}$. For the purpose of conducting sieved composition (i.e. granulometric, sized) analysis, the wastes collected were sieved through sieve of mesh size: $>100 \mathrm{~mm}, 40 \mathrm{~mm}, 20 \mathrm{~mm}$,
$10 \mathrm{~mm}$ (sieved fraction $<10 \mathrm{~mm}$ was obtained in this way). Next, the wastes were segregated by hand and sorted to obtain 34 material fractions and subfractions (morphological). Division into individual groups and their denotation was performed on the basis of Jędrczak and Szpadt [Szpadt, Jędrczak, 2006] (description in Table 1). In the biowastes accumulated moisture content, $\mathrm{pH}$, Corg, Nog, Pog and ions: $\mathrm{Na}, \mathrm{K}, \mathrm{Ca}, \mathrm{Mg}, \mathrm{Zn}$, $\mathrm{Cu}$ were determined. The value of $\mathrm{pH}$ was measured in water extracts of analyzed samples, by potentiometric method. Organic carbon content was determined by the Tiurin method. Total nitrogen was determined colorimetrically by means of indophenol reaction using spectrophotometer UV/VIS 916 of the firm GBC. Quantity of total phosphorus was established applying the colorimetric method using molybdenum blue. Micro and macro content of the components in organic wastes was determined by using ICP Integra spectrometer of the firm GBC. Quantity of heavy metals in the ashes analyzed was established by ASA method using spectrometer Solaar $6 \mathrm{M}$ of the firm Thermo.

\section{RESULTS AND DISCUSSION}

The sum of wastes generated during the four analyzed seasons - 1 year, in the households under study, per 1 person, amounted to $170,3 \mathrm{~kg}$ (in wet mass basis). The result is very similar to the data of the statistical yearbook of waste collected from household presented by GUS [Environment, 2013]. Research at households at rural areas in Poland conducted by Strzelczyk (2013) showed that, average amount of waste generated per capita is $180 \mathrm{~kg}$ per year. In own study for 1 person, most domestic waste was generated in autumn $-45,5 \mathrm{~kg}$ per capita, and the least in winter $-39,0 \mathrm{~kg}$ per capita (Table 2). According to the data [Burnley, 2007; Hoornweg, BhadaTata, 2012] the average production of wastes in countries of OECD amounts to $2.1 \mathrm{~kg} /$ person/ day, although in extreme cases even up to $14 \mathrm{~kg} /$ person/day. In the light of such data, the results obtained from our studies indicate that in such households significantly less wastes is generated than the average in OECD countries [Hoornweg, Bhada-Tata, 2012].

Not without significance is the location of the households analyzed. Statistical data obtained for the whole country may differ considerably from 
Table 1. Material structure of size fractions from household wastes - on average for the 4 seasons (spring, summer, autumn and winter)

\begin{tabular}{|c|c|c|c|c|c|c|}
\hline \multirow{2}{*}{ Material structure of size fractions (\%) } & \multicolumn{6}{|c|}{ Fraction } \\
\hline & Symbol & $>100 \mathrm{~mm}$ & $40-100 \mathrm{~mm}$ & $20-40 \mathrm{~mm}$ & $10-20 \mathrm{~mm}$ & $<10 \mathrm{~mm}$ \\
\hline Kitchen waste & OR1 01 & 9.13 & 44.18 & 45.25 & 28.28 & 13.23 \\
\hline Garden waste & OR1 02 & 4.82 & 2.86 & 47.99 & 57.90 & 18.75 \\
\hline Other organic wastes & OR1 03 & 1.66 & 0.22 & 0.84 & 1.72 & 5.97 \\
\hline Non-treated wood & W2 01 & - & 0.03 & 0.01 & 0.02 & 0.01 \\
\hline Treated wood & W2 02 & 0.03 & 0.04 & 0.01 & 0.03 & - \\
\hline Glittering paper. wallpaper & PC3 01 & 0.21 & 0.12 & - & - & - \\
\hline Packaging paper and cardboard & PC3 02 & 3.50 & 1.69 & 0.07 & 0.15 & - \\
\hline Newspapers and magazines & PC3 03 & 5.70 & 0.13 & & & - \\
\hline Other paper and cardboard non-packaging & PC3 04 & 1.37 & 4.34 & 0.87 & 1.79 & - \\
\hline Packaging film & PL4 01 & 1.96 & 0.86 & 0.08 & 0.17 & - \\
\hline Non-packaging film & PI4 02 & 1.73 & 1.60 & 0.05 & 0.11 & - \\
\hline Other packaging plastic & PL4 04 & 9.53 & 5.79 & 0.58 & 1.20 & - \\
\hline Other non-packaging plastic & PL4 05 & 1.08 & 1.24 & 0.21 & 0.44 & - \\
\hline Packaging glass - white & G5 01 & 5.56 & 20.43 & 0.57 & 1.17 & - \\
\hline Packaging glass - brown & G5 02 & 0.79 & 2.43 & - & - & - \\
\hline Other packaging glass & G5 03 & 3.89 & 2.86 & 0.15 & 0.31 & - \\
\hline Other non-packaging glass & G5 04 & 1.43 & 0.44 & 0.03 & 0.06 & - \\
\hline Textiles - clothes & T6 01 & 2.15 & 0.62 & 0.02 & 0.05 & - \\
\hline Textiles - other & T6 02 & 1.24 & 0.45 & 0.05 & 0.10 & - \\
\hline Ferrous metal packaging & M7 01 & 0.62 & 2.99 & 0.19 & 0.37 & - \\
\hline Non-ferrous packaging & M7 02 & 0.87 & 0.82 & 0.06 & 0.13 & 0.01 \\
\hline Other ferrous metal & M7 03 & 0.31 & 0.21 & 0.10 & 0.22 & 0.03 \\
\hline Other non-ferrous metal & M7 04 & 0.20 & 0.20 & 0.04 & 0.08 & 0.06 \\
\hline Batteries & H8 01 & - & - & 0.17 & 0.34 & - \\
\hline Other potentially hazardous & H8 02 & - & 0.20 & 0.02 & 0.01 & - \\
\hline Multi component packaging & C9 01 & 4.98 & 3.92 & 0.36 & 0.73 & - \\
\hline Non-multicomponent packaging & C9 02 & 1.59 & 0.76 & 0.19 & 0.40 & - \\
\hline WEEE & C9 03 & 0.30 & 0.16 & 0.21 & 0.43 & - \\
\hline Ashes & & - & 0.05 & 0.97 & 1.97 & 59.24 \\
\hline Disposable nappies & U11 01 & 29.56 & - & - & - & - \\
\hline Identifiable clinical wastes & U11 02 & 2.30 & - & 0.03 & 0.06 & - \\
\hline Other categories & U11 03 & 3.49 & 0.60 & 0.85 & 1.74 & 0.58 \\
\hline Fine fraction & F12 & - & - & 0.01 & 0.01 & 1.57 \\
\hline Inert waste & IN1002 & - & - & 0.01 & 0.02 & 0.56 \\
\hline Total & $\%$ & 100.00 & 100.00 & 100.00 & 100.00 & 100.00 \\
\hline
\end{tabular}

the results obtained in studies on outskirts or of specific character. According to statistical data, the coefficient of wastes collected in Denmark amounts to $650 \mathrm{~kg} /$ person/year, however, according to the studies conducted in Sisimut, the mass of wastes amounts only to $133 \mathrm{~kg} /$ person/year [Eisted, Christensen, 2011; Environment, 2013]. In Poland total mass of municipal waste collected in 2012 year was $248,6 \mathrm{~kg}$ per capita/year [Environment, 2013]. Estimating the quantity of wastes generated (which is most often performed on the basis of statistical indicators) has basic significance for planning all investments in waste management. It must therefore be based on most reliable data. It should be noted that the waste stream is affected by several elements (e.g. location, financial capability of the residents, cultural factors and demography, season of year, dietary habits, having a pet, waste disposal in their own estate, type of heating fuel used). Seasons obvi- 
Table 2. Material composition of wastes generated in suburban households in the seasons

\begin{tabular}{|c|c|c|c|c|}
\hline Material composition of wastes in 4 seasons (\%) & Spring & Summer & Autumn & Winter \\
\hline Kitchen waste & 27.7 & 30.9 & 34.1 & 39.3 \\
\hline Garden waste & 28.6 & 27.1 & 13.9 & 11.3 \\
\hline Wood (total) & 0.03 & 0.04 & 0.02 & 0.04 \\
\hline Paper and Cardboard (total) & 3.18 & 6.24 & 6.56 & 4.88 \\
\hline Packaging plastic (total) & 3.98 & 5.80 & 6.30 & 5.01 \\
\hline Non-packaging plastic (total) & 1.68 & 1.73 & 2.21 & 1.06 \\
\hline Galss (total) & 11.21 & 10.07 & 12.06 & 9.56 \\
\hline Textiles (total) & 1.40 & 1.12 & 1.25 & 1.15 \\
\hline Ferrous waste (total) & 0.70 & 1.15 & 2.27 & 1.40 \\
\hline Non-ferrous waste (total) & 0.50 & 0.51 & 0.96 & 0.63 \\
\hline Hazardous waste (total) & 0.03 & 0.02 & 0.42 & 0.10 \\
\hline Multi component packaging & 2.01 & 2.71 & 3.24 & 2.49 \\
\hline Non-multicomponent packaging & 0.71 & 0.62 & 0.88 & 0.65 \\
\hline WEEE & 0.56 & 0.04 & 0.01 & 0.02 \\
\hline Ashes & 6.46 & 1.51 & 1.15 & 10.15 \\
\hline Disposable nappies & 7.23 & 6.13 & 10.45 & 9.26 \\
\hline Identifiable clinical wastes & 0.38 & 0.81 & 0.64 & 0.72 \\
\hline Other categories & 2.76 & 1.17 & 0.30 & 0.09 \\
\hline Fine fraction & 0.14 & 0.33 & 0.19 & 0.20 \\
\hline Inert waste & - & 0.24 & - & 0.01 \\
\hline The weight $(\mathrm{kg})$ of waste packaging produced per capita per season & 10.9 & 10.8 & 8.2 & 7.3 \\
\hline The weight of waste produced per capita $(\mathrm{kg})$. Avg \pm SD & $44.2 \pm 27.6$ & $41.6 \pm 17.5$ & $45.5 \pm 33.2$ & $39 \pm 17.3$ \\
\hline Average yearly total weight of waste produced per capita $(\mathrm{kg})$. Avg $\pm S D$ & \multicolumn{4}{|c|}{$170.3 \pm 58.8$} \\
\hline
\end{tabular}

* Analyzed wastes made from one kind of material are listed summarily.

Avg - average of analyzed households, SD - standard deviation.

ously influenced the size of furnace and garden waste stream in analyzed households (Table 2).

The studies of wastes from the angle of size composition belong to the basic type. They are significant for planning the technological line for sorting wastes. The largest fraction $(>100 \mathrm{~mm})$ contains mainly secondary raw materials (specially packaging), as well as garden wastes (branches, trees), easy for mechanical separation. They mainly constitute combustible wastes of high calorific value and low moisture content. The next important fraction, from the point of view of mechanical sorting, is the group of wastes of size up to 20 $\mathrm{mm}$, since the mesh of sieves of this size forms a practical limit of mechanical segregation. Sieves of lower mesh are blocked by organic material in the wastes. The analysis performed of sieved composition (size fraction) showed that fractions: $>100 \mathrm{~mm}, 40-100 \mathrm{~mm}, 20-40 \mathrm{~mm}$ constituted totally $80 \%$ of the mass of wastes (average in a year) (Figure 1). The lowest fraction $(<10 \mathrm{~mm})$ whose significant part constitutes ashes, varied depending on the season of year: from $3.5 \%$ to $12.8 \%$.
One of the largest problem of mechanical segregation is separating kitchen and garden wastes (viz. biowastes) and polluting other morphological fractions with them. Sorting biowastes "at source" enables obtaining secondary raw materials of better quality and more attractive for processing units. This concerns not only packaging waste paper, etc. It is also very important for further procedures with biowastes towards their biological utilization. Separation of "bio" fractions by residents was practiced mainly in rural or other areas, if the owner of the property had composting facility by the house and wanted to utilize biowastes himself for composting.

In the morphological composition of the households analyzed (on average in 4 seasons), biowastes (kitchen and garden waste) totally formed over $53 \%$ of the whole mass of wastes and this value is higher than data from literature. Depending on the applied mode of collecting wastes, the share of this group of wastes in other countries of Europe amounted to approx. 40\% [Burnley, Flowerdew, Poll, Prosser, 2007; Gallardo, 
Bovea, Colomer, Prades, 2012]. Application of the 3-bag method in the study conducted was significantly more effective for the segregated wet fraction. Seasonal composition of biodegradable part of wastes disposed in the investigated households was variable. The share of biodegradable waste in the whole mass of waste generated in analyzed households was $61 \%$ (annual average). The households analyzed did not conduct any cultivation by the house for own requirements. The garden wastes formed came from nurturing procedures of lawns and flower beds. Their share in the mass of biowastes amounted to about $11 \%$ to $23 \%$, depending on the season of the year (Figure 2). The main part of biowaste are kitchen waste but seasonal variability, size and way of property organization changes the proportion of biowaste. In our study, the share of garden waste (average per year) was $20 \%$ and was similar to the Czech Republic results in Prague [Hanc, Novak, Dvorak, Habart, Svehla, 2011]. It also showed that the weight of kitchen waste per capita per year was $50 \mathrm{~kg}$.

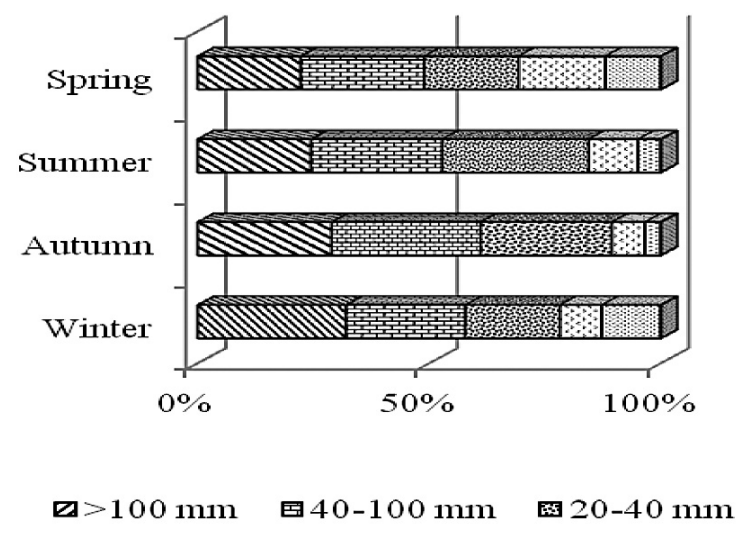

Figure 1. Share of size fractions of wastes from households, depending on season of the year
Additionally, detached houses formed approximately $1 \mathrm{~kg}$ of garden waste $/ 1 \mathrm{~m}^{2}$ property. Studies conducted by Kotvicova (2010, 17.04.2014) have also shown that biowastes dominated in the total weight of waste generated in households. In addition, the author has shown that the most biowaste were developed in four persons families in multi-family block of flats estates.

Waste packaging is a valuable source of secondary raw materials. The market value of this waste depends largely on the degree of their contamination. Waste segregation "at source" allows to obtain the highest efficiency of separation and least polluted (especially by organic waste). In the analyzed households one person generated about $37 \mathrm{~kg}$ of waste packaging per year. Share of packaging waste (glass, paper and cardboard, plastics) in household waste was significant and accounted approximately $22 \%$ (average per year). The largest share (by weight) was glass waste (mainly white) due to the properties of this type of packaging material. A group of plastic packag-

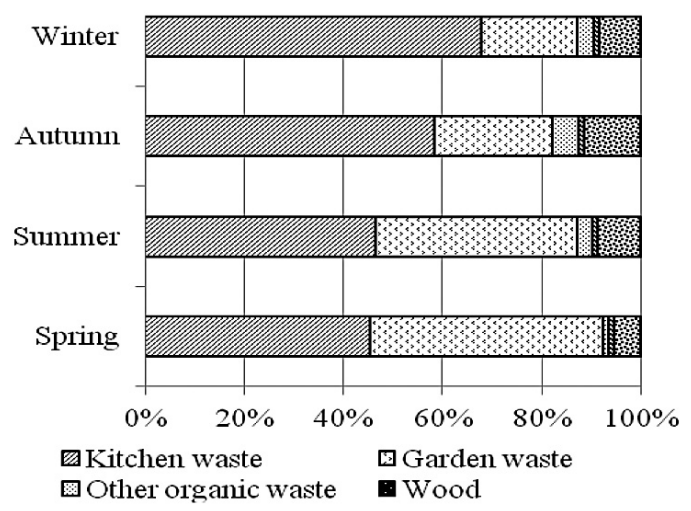

Figure 2. Share of morphological fractions of biodegradable wastes from households, depending on season of the year. The share of wood: spring and autumn: both $0,02 \%$, summer and winter: both $0,04 \%$

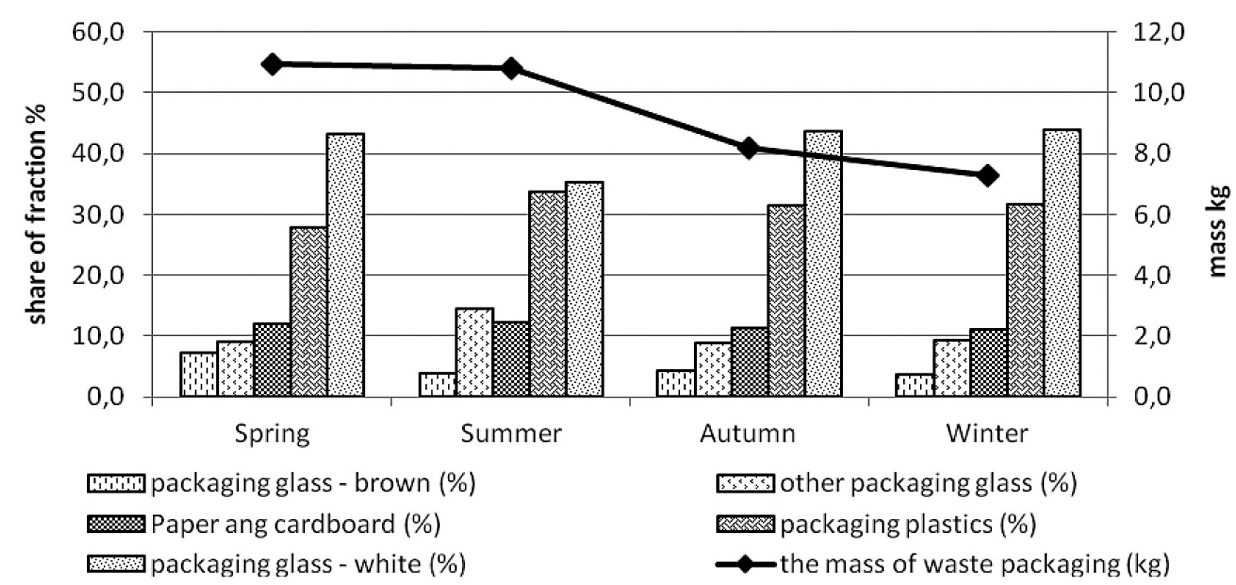

Figure 3. Waste packaging structure $(\%)$ and weight $\left(\mathrm{kg}\right.$ per capita*year $\left.{ }^{-1}\right)$ in household at suburban areas 
ing is worth mentioning. Its share in the mass of packaging waste ranged (depending on season) from $28 \%$ to $34 \%$ (Figure 3). Plastic packaging waste even though their unit of weight is small occupy a very large volume. It is important in the aspect of waste management system designing in the community, the number of containers in the household and the organization of collection and transport of waste.

Analysis of morphological composition of size fractions showed that the largest mass in the fraction $>100 \mathrm{~mm}$ constituted disposable diapers (about 30\%). The second with respect to mass was the group of wastes from plastics (PL4). The fraction $>100 \mathrm{~mm}$ contained over $14 \%$ of them including over $80 \%$ of plastic packaging. Paper and cardboard (mainly newspapers) formed about $9 \%$ of the mass of this fraction size.

Dominating in the second fraction of size $100-40 \mathrm{~mm}$, were biowastes (47\% mass) and glass waste - over $26 \%$ mass of the whole fraction. Over $80 \%$ of glass waste constituted packaging wastes of white (colourless) glass. The consecutive fractions (40-20 mm and 20-10 mm) almost wholly consisted of biowastes constituting $93.2 \%$ and $86.2 \%$ of wastes mass, respectively. The remaining groups did not exceed $2 \%$ share of the mass of the given fraction. The so-called "under-sieve" fraction, obtained after passing through sieves of the smallest mesh consisted up to almost $60 \%$ of ashes and $1 / 3$ of biowastes (Table 1). The ashes can be traditionally used for sprinkling pathways on the household site during winter. From the analyses of morphological wastes (Table 2) it is concluded that irrespective of the season of the year, having the largest share in the mass are biowastes, then glass wastes and used disposable diapers. Due to heating season, ashes indicate seasonal variations. The results of extensive studies of municipal wastes in Wales [Burnley et al., 2007] vary slight. In these studies, the \% age share of paper amounted to approx. $23 \%$, share of biowastes was lower, slightly more than $35 \%$, whereas more metal waste. The differences obtained in the results may be caused by different ways of accumulating domestic wastes. In the studies carried out in Spain and in the Balkans, comparing different systems of sorting wastes right at the place of their generation (households), the most effective turned out to be the 4-bag system (similar to that applied on the outskirts of Wrocław), separated in which was the kitchen-garden fraction. This enabled obtain- ing 37\% of biowastes [Gallardo et al., 2007; Vaccari, Di Bella, Vitali, Collivignarelli, 2013]. This, however, is significantly less than the result of our studies.

Thanks to separation of the "bio" fraction from other wastes, dry, clean raw material easy for mechanical segregation is obtained. From the studies of wastes conducted from the areas of suburban rural districts, it was ascertained that on sieves of mesh $>100 \mathrm{~mm}, 97 \%$ of newspapers, over $60 \%$ of packing bags of foil and $75 \%$ of textiles are held back.

In fractions practically impossible for mechanical sorting such as $10-20 \mathrm{~mm}$ and $<10 \mathrm{~mm}$, they mainly comprise: ashes, inert and minor wastes as well as biowastes. Knowledge of material structures of individual fractions is important from the point of view of the possibility of utilizing the wastes and further procedures with them (Table 3).

The characteristics of wastes obtained in the households analyzed are similar to the data contained concerning municipal wastes of various Polish towns - Kraków (Cracow), Zgorzelec [Den Boer, Jędrczak, Kowalski, Kulczycka, Szpadt, 2010]. Although the data concerning studies in rural areas are from many years back [Skalmowski, Skalmowski, 2006], even then the characteristics of "wastes" from areas bordering with towns were similar to the characteristics of urban wastes.

The analysis of basic chemical components of biowastes showed that in case of utilizing them for production of compost, it would be necessary to modify (correct) the ratios $\mathrm{C} / \mathrm{N}$ and $\mathrm{C} / \mathrm{P}$. The results obtained for $\mathrm{C} / \mathrm{N}$ (between 13.7-18) and $\mathrm{C} / \mathrm{P}$ (between 97.9-309.5) depending on the size fraction, do not ensure the proper process of composting [Sebastian, Szpadt, 1999; Czyżyk, Kozdraś, 2004]. The ratios recommended in literature for $\mathrm{C} / \mathrm{N}$ and $\mathrm{C} / \mathrm{P}$ of the components composted should not exceed 30:1, 100, respectively, moisture content up to $60 \%$ and reaction should be approximately neutral [Kasprzak, 1998]. To correct these ratios, it would be necessary to add sawdust, straw, hay to these wastes (for correcting $\mathrm{C} / \mathrm{N}$ ), and for correcting the ratio $\mathrm{C} / \mathrm{P}-$ e.g. superphosphate (Table 4).

The analysis of chemical composition showed that the biowastes were characterized by very high moisture content and neutral $\mathrm{pH}$ (Table 4). Such high water content is due to the large proportion of kitchen wastes. The analysis of chemical components presented by Kumar et al. [Kumar et al. 2010] confirms high moisture content and 
Table 3. Size structure, in individual material groups of wastes from suburban households (with the exception of OR1 01, 02, 03) in \%

\begin{tabular}{|c|c|c|c|c|c|c|}
\hline \multirow{2}{*}{$\begin{array}{l}\text { Size structure. in individual material groups of wastes } \\
\text { (with the exception of OR1 01.02.03) (\%) }\end{array}$} & \multicolumn{5}{|c|}{ Fraction (mm) } & \multirow{2}{*}{ Total $(\%)$} \\
\hline & $>100$ & $40-100$ & $20-40$ & $10-20$ & $<10$ & \\
\hline Non-treated wood & 2.50 & 37.87 & 22.96 & 29.85 & 6.82 & 100.00 \\
\hline Treated wood & 4.85 & 32.55 & 59.54 & 3.05 & - & 100.00 \\
\hline Glittering paper. wallpaper & 61.54 & 38.40 & 0.06 & 0.00 & - & 100.00 \\
\hline Packaging paper and cardboard & 49.25 & 49.72 & 0.98 & 0.05 & - & 100.00 \\
\hline Newspapers and magazines & 97.66 & 2.34 & 0.00 & 0.00 & - & 100.00 \\
\hline Other paper and cardboard non-packaging & 20.02 & 66.47 & 12.24 & 1.27 & - & 100.00 \\
\hline Packaging film & 67.33 & 30.15 & 2.15 & 0.36 & - & 100.00 \\
\hline Non-packaging film & 49.39 & 49.83 & 0.78 & 0.01 & - & 100.00 \\
\hline Other packaging plastic & 59.32 & 36.62 & 3.57 & 0.49 & - & 100.00 \\
\hline Other non-packaging plastic & 40.18 & 48.60 & 8.13 & 3.08 & - & 100.00 \\
\hline Packaging glass - white & 20.59 & 77.23 & 2.12 & 0.06 & - & 100.00 \\
\hline Packaging glass - brown & 29.12 & 70.88 & 0.00 & 0.00 & - & 100.00 \\
\hline Other packaging glass & 57.72 & 40.39 & 1.76 & 0.14 & - & 100.00 \\
\hline Other non-packaging glass & 68.65 & 28.57 & 1.69 & 1.08 & - & 100.00 \\
\hline Textiles - clothes & 75.76 & 23.30 & 0.77 & 0.18 & - & 100.00 \\
\hline Textiles - other & 55.11 & 40.42 & 4.32 & 0.15 & - & 100.00 \\
\hline Ferrous metal packaging & 16.09 & 79.26 & 4.32 & 0.34 & - & 100.00 \\
\hline Non-ferrous packaging & 46.92 & 49.01 & 3.29 & 0.65 & 0.13 & 100.00 \\
\hline Other ferrous metal & 23.03 & 33.49 & 19.58 & 23.81 & 0.09 & 100.00 \\
\hline Other non-ferrous metal & 34.33 & 48.61 & 10.53 & 3.38 & 3.15 & 100.00 \\
\hline Batteries & - & 0.00 & 46.05 & 53.95 & - & 100.00 \\
\hline Other potentially hazardous & - & 58.87 & 13.37 & 27.76 & - & 100.00 \\
\hline Multi component packaging & 53.29 & 42.60 & 3.56 & 0.54 & - & 100.00 \\
\hline Non-multicomponent packaging & 60.96 & 30.76 & 6.62 & 1.66 & - & 100.00 \\
\hline WEEE & 12.44 & 49.47 & 13.47 & 24.62 & - & 100.00 \\
\hline Ashes & - & 0.13 & 8.28 & 21.56 & 70.04 & 100.00 \\
\hline Disposable nappies & 100.00 & - & - & - & - & 100.00 \\
\hline Identifiable clinical wastes & 99.02 & - & 0.98 & - & - & 100.00 \\
\hline Other categories & 22.90 & 25.00 & 17.31 & 34.17 & 0.62 & 100.00 \\
\hline Fine fraction & - & - & 1.04 & 13.94 & 85.01 & 100.00 \\
\hline Inert waste & - & - & 0.64 & 0.00 & 99.36 & 100.00 \\
\hline
\end{tabular}

unfavourable ratio $\mathrm{C} / \mathrm{N}$ in kitchen wastes which should be modified for the composting process. The contents of elements in biowastes obtained in our studies were similar to the data from literature [Boldrin, Christensen, 2010].

Composting biowastes is the most recommended method of their utilization. Rural areas have the highest possibility in this respect and this method is the cheapest and commonly used in rural households. The situation, however, changes when it concerns suburban areas. The households analyzed in the paper had neither been prepared nor were interested in composting on the area of the property where the biowastes were gen- erated. Given as a reason was lack of space on the property, organizational difficulties, lack of interest in such a method and absence of the possibility of utilizing the compost obtained on the area of their property. In the context of the results obtained $(53 \%$ of the total mass of wastes being biowastes), utilization of the biowastes in the place where they were generated would enable reducing the stream of wastes transferred. From the environmental point of view, it is very desirable not only because of decreasing the stream of municipal wastes but also related to the most recommended method of biowastes utilizing (for agricultural purposes). According to various authors 
Table 4. Basic chemical parameters of biowastes determining their usefulness for composting (average for the 4 seasons)

\begin{tabular}{|c|c|c|c|c|c|c|}
\hline \multirow{2}{*}{ Symbol } & \multirow{2}{*}{ Unit } & \multicolumn{5}{|c|}{ Fraction $(\mathrm{mm})$} \\
\cline { 3 - 7 } & & $>100$ & $40-100$ & $20-40$ & $10-20$ & $<10$ \\
\hline $\mathrm{C}_{\text {org }}$ & {$[\mathrm{mg} / \mathrm{g}]$} & 319.02 & 332.18 & 351.38 & 366.57 & 378.48 \\
\hline $\mathrm{N}_{\text {ogk }}$ & {$[\%]$} & 84.10 & 78.80 & 77.80 & 68.10 & 77.20 \\
\hline $\mathrm{P}_{\text {og }}$ & {$[\mathrm{mg} / \mathrm{g}]$} & 19.12 & 18.45 & 22.62 & 26.66 & 25.51 \\
\hline $\mathrm{C} / \mathrm{N}$ & {$[\mathrm{mg} / \mathrm{g}]$} & 1.92 & 1.07 & 2.71 & 3.75 & 1.61 \\
\hline $\mathrm{C} / \mathrm{P}$ & - & 16.7 & 18.0 & 15.5 & 13.7 & 14.8 \\
\hline $\mathrm{Na}$ & - & 166.6 & 309.5 & 129.8 & 97.9 & 235.1 \\
\hline $\mathrm{K}$ & {$[\mathrm{mg} / \mathrm{g}]$} & 6.12 & 3.35 & 4.46 & 6.26 & 5.89 \\
\hline $\mathrm{Mg}$ & {$[\mathrm{mg} / \mathrm{g}]$} & 18.96 & 21.75 & 16.49 & 13.25 & 10.26 \\
\hline $\mathrm{Ca}$ & {$[\mathrm{mg} / \mathrm{g}]$} & 2.53 & 2.09 & 2.02 & 1.82 & 1.92 \\
\hline $\mathrm{Zn}$ & {$[\mathrm{mg} / \mathrm{g}]$} & 47.32 & 48.46 & 43.80 & 26.98 & 39.49 \\
\hline $\mathrm{Cu}$ & {$[\mathrm{mg} / \mathrm{g}]$} & 0.0265 & 0.0499 & 0.0579 & 0.0735 & 0.1206 \\
\hline $\mathrm{pH}$ & {$[\mathrm{mg} / \mathrm{g}]$} & 0.021 & 0.018 & 0.015 & 0.025 & 0.092 \\
\hline Moisture content & - & 6.06 & 6.36 & 6.37 & 6.18 & 6.33 \\
\hline & {$[\%]$} & 86.2 & 76.8 & 91.3 & 83.4 & 73.2 \\
\hline
\end{tabular}

[Burnley, 2007; What a Waste: A global review of solid waste management, 11.04.2014] depending on economical conditions of the society, the proportion of this group of wastes amounts from $20 \%$ to $75 \%$ of the total mass of waste.

It is therefore possible to reduce the mass of wastes directed for utilization by such a quantity in special installations and prevent pollution of the remaining wastes which must be transferred to the authorized party, in accordance with the prevailing regulations. Encouraging the residents for biowastes composting on their own property area enables to reduce significantly the costs of biowastes management system and it is very desirable for environmental reasons. The segregated biowastes from the whole stream enables obtaining other kinds of wastes in relatively clean condition facilitating further processing and making them more attractive commercially. Rural areas create very high possibilities for utilizing composts. If however there are regions in rural areas which differ considerably by their character from rural characteristics, detailed data should be obtained relating to wastes generated in specific types of structures and the arrangement or proportion of individual environments on the terrain of the district should be specified.

If the residents do not envisage the possibility of composting wastes in the vicinity of the household property, it is essential to study the chemical characteristics of biowastes (their various components) to assess the environmental benefits, management of such wastes and the possibility of their utilization.

Not all composition biowastes can be composted in domestic conditions and the usefulness of individual components for methods of biological utilization varies.

\section{CONCLUSIONS}

1. Municipal wastes generated in households on suburban areas of rural districts have the character of wastes generated in urban households.

2. Biodegradable wastes constitute over half the mass in the stream of wastes generated in suburban households.

3. Biowaste segregation and their composting by those generating them (residents) in the place where they are created reduces the stream of wastes transferred from individual households by about $50 \%$. Separating the organic fraction of waste, which is suitable for composting and reusing on farm can effectively reduce the amount of waste going to landfill.

4. The share of waste packaging mass in the mass of waste generated in households in suburban areas accounted about $22 \%$.

5. Waste segregation ,at source", especially the separation of the organic fraction of waste stream, allows to obtain secondary raw materials of high quality parameters. 


\section{Acknowledgements}

The studies were carried out within the framework of the long-term program for the years 2011-2015 "Standardization and monitoring of the environmental undertakings, agricultural technique and infrastructural solutions for safety and balanced development of agriculture and rural areas" - Resolution No. 202/2011 of the Council of Ministers dated 14 October 2011.

\section{REFERENCES}

1. Boldrin A., Christensen T.H. 2010. Seasonal generation and composition of garden waste in Aarhus (Denmark). Waste Management 30, 551-557.

2. Burnley S.J. 2007. A review of municipal solid waste composition in the United Kingdom. Waste Management 27, 1274-1285.

3. Burnley S.J., Ellis J.C., Flowerdew R., Poll A.J., Prosser H. 2007. Assessing the composition of municipal solid waste in Wales. Resources, Conservation and Recycling 49, 264-283.

4. Central Bureau for Statistics (GUS) 2013. Environment. Warsaw.

5. Central Bureau for Statistics (GUS) 2012. The results of National Census Population and Housing. Warsaw.

6. Central Bureau for Statistics (GUS) 2013. Population. Status and demographic and social structure. Warsaw.

7. Czyżyk F., Kozdraś M. 2004. Chemical properties and composting of sludge from rural wastewater treatment plant. Water -Environment- Rural Areas. 4, 2a (11), 559-569 (in polish).

8. Den Boer E., Jędrczak A., Kowalski Z., Kulczycka, Szpadt R. 2010. A review of municipal solid waste composition and quantities in Poland. Waste Management 30, 369-377.

9. Eisted R., Christensen T.H. 2011. Characterization of household waste in Greenland. Wast Management 31 (7), 1461-1466.

10. Gallardo A., Bovea M., Colomer F.J., Prades M. 2012. Analysis of collection systems for sorted household waste in Spain. Waste Management 32, 1623-1633.
11. Hanc A., Novak P., Dvorak M., Habart J., Svehla P. 2011. Composition and parameters of household bio-waste in four seasons. Waste Management 31, 1450-1460.

12. Hoornweg D., Bhada-Tata P. 2012. What a Waste, A Global Review of Solid Waste Management. Urban Development Series Knowledge Papers. (15), 3-116. From http://www-wds.worldbank.org/external/default/WDSContentServer/WDSP/IB/201 2/07/25/000333037_20120725004131/Rendered/ PDF/681350WP0REVIS0at0a0Waste20120Final. pdf [access: 14.04.2014].

13. Kotvicova J. 2010. Analysis of household waste composition and segregation in Blansko city. Infrastructure and ecology of rural areas. 8/2, 117126. From http://www.infraeco.pl/pl/art/a_16052. htm?plik=879 (17.04.2014)

14. Kasprzak K. 1998. Theoretical and practical requirements for organic waste composting. [In:। Municipal Enterprise and the Environment. IX Conference Poznań, Abrys, 125-238 (in polish).

15. Kumar M., Ou Y-L., Lin J-G. 2010. Co-composting of green waste and food waste at low $\mathrm{C} / \mathrm{N}$ ratio. Waste Management 30, 602-609.

16. Sebastian M., Szpadt R. 1999. Individual composting of garden biowaste at home composting facility. In: Composting and disposal of compost. I Technical Sciences Conference. Puławy-Warsaw. IOŚ, IUNG, PTIE, 117-124 (in Polish).

17. Skalmowski K., Skalmowski A. 1996. Types of waste at rural areas and small towns. Ecological Guide for Local Government, 2 (in Polish).

18. Strzelczyk M. 2013. Structure and properties of municipal wastes from rural households in the aspect of the possibilities of their processing and legal regulations. Water-Environment-Rural Areas, Monography, 113, ITP Falenty (in Polish).

19. Szpadt R., Jędrczak,A. 2006. Research methodology to determine the composition of the sieve, morphological and chemical waste. (in Polish). From http://www.mos.gov.pl/g2/big/2009_04/0406c54fa 55c86fb5c4548561bc4bce6.pdf [access: 11.04.2014].

20. Vaccari M., Di Bella V., Vitali F., Collivignarelli C. 2013. From mixed to separate collection of solid waste: Benefitsfor the town of Zavidovic'i (Bosnia and Herzegovina). Waste Management 33, 277-286. 